\title{
An investigation into the effects of extensive listening on pre- intermediate learners' English vocabulary learning at The Asian International School
}

\author{
Nguyen Ngoc Ly ${ }^{1}$, Nguyen Thuy $\mathrm{Nga}^{2 *}$ \\ ${ }^{1}$ The Asian International School, Vietnam \\ ${ }^{2}$ Ho Chi Minh City Open University, Vietnam \\ *Corresponding author: nga.nt@ou.edu.vn
}

\begin{tabular}{|c|c|}
\hline ARTICLE INFO & ABSTRACT \\
\hline $\begin{array}{l}\text { Keywords: } \\
\text { intensive listening, extensive } \\
\text { listening, receptive } \\
\text { vocabulary knowledge, } \\
\text { productive vocabulary } \\
\text { knowledge, listening } \\
\text { vocabulary levels test }\end{array}$ & $\begin{array}{l}\text { Nowadays, most learners, especially students at The Asian } \\
\text { International School, have plenty of opportunities for learning } \\
\text { English vocabulary from the earliest possible age. However, the } \\
\text { students in general faced lots of difficulties in vocabulary } \\
\text { learning. Thus, the study was conducted with the purpose to } \\
\text { investigate to what extent extensive listening affected the } \\
\text { students' vocabulary learning and their listening habits. Eighty } \\
\text { participants were chosen by using convenience sampling and } \\
\text { divided into two groups: a control group and an experimental } \\
\text { group. The two groups took a pretest to measure their vocabulary } \\
\text { knowledge with Listening Vocabulary Levels Test. Then, besides } \\
\text { studying the school's formal English curriculum, the control } \\
\text { group practiced intensive listening while the experimental group } \\
\text { practiced extensive listening. All the participants were required to } \\
\text { submit one listening journal each week to report what they have } \\
\text { done as their listening habits. Finally, they took a posttest } \\
\text { (Listening Vocabulary Levels Test) after } 12 \text { weeks practicing. } \\
\text { The results showed that extensive listening could help to increase } \\
\text { the participants' receptive vocabulary knowledge significantly, } \\
\text { including word meanings and word aural forms. Additionally, the } \\
\text { more the participants practiced extensive listening, the higher } \\
\text { improvement they somewhat had on receptive vocabulary } \\
\text { knowledge. The participants tended to practice listening by using } \\
\text { visual materials and self-selected materials in their listening } \\
\text { habits. To sum up, extensive listening affected impressively the } \\
\text { participants' vocabulary learning that aspires for the study to } \\
\text { propose suggestions for future studies so that administrators, } \\
\text { teachers, and students could receive huge pedagogical } \\
\text { implications of extensive listening. }\end{array}$ \\
\hline
\end{tabular}




\section{Introduction}

Vocabulary is considered as one of the most important things in foreign language learning. Several researchers have proved that learning vocabulary is crucial because nothing could be transferred if there is a lack of vocabulary (Larsson, 2014; Nation, 2008; Wilkins, 1972, as cited in Thornburry \& Harmer, 2002; Viera, 2017). To learn a word, N. Schmitt (2000) suggested that learners could obtain both receptive and productive vocabulary knowledge. N. Schmitt (2000) stated that receptive vocabulary knowledge is the ability to understand a word in listening and reading while productive vocabulary knowledge expects learners to use a word in speaking and writing. However, acquiring all aspects of vocabulary leads learners to get troubles when they study vocabulary. For example, learners seemed to forget the words they have learned if they did not meet the words repeatedly (Nation, 2007). They had to catch up with big problems with studying word meanings, pronunciations, and spellings (Higa, 1965, as cited in Nation, 2001; Renandya \& Farell, 2011; Sedau, 2004). The way to measure the word knowledge is also another difficulty for them (Rahmawati, 2012; Rohmatillah, 2017). To sum up, learners, in general, have difficulty when studying vocabulary.

In Vietnamese contexts, learners also turn the difficulty up when they learn English vocabulary. It was stated by Nguyen and Pham (2016) that 400 students in Hanoi had problems in learning English vocabulary. Besides, the limitation of vocabulary size also made students get low scores in tests (H. P. H. Le, 2001). At the Asian International School, the research site, students also get into difficulties in vocabulary learning although they have several opportunities to study and use vocabulary fluently. Being a teacher at the school, the researcher notices that the students tried hard to interpret the speakers' meanings because of unknown vocabulary. They did not frequently get high scores in listening or speaking due to lacking vocabulary or forgetting the words they've learned. However, the above difficulties are observed personally from the teacher's viewpoints; up to this time, there has been no formal research examining how to deal with these problems.

There is convincing evidence of positive effects of a new way to learn vocabulary extensive listening could enhance vocabulary knowledge by inspiring learners to listen to the appropriate materials which they are interested in for pleasure and whenever they have free time (Ucán, 2010; Waring, 2008). Previous studies investigate the effects of extensive listening on vocabulary learning both in receptive and productive knowledge, but the results are infrequently as expected in productive vocabulary knowledge. That could be listening is a receptive skill, which gives spoken information from a speaker to a listener and does not require listeners to use language (Aguilera \& Filologia, 2012; Tavil, 2010). Hence, this study intends to focus on the advantages of extensive listening to learners' receptive vocabulary knowledge only. Extensive listening is considered as an appropriate method to help learners increase their vocabulary knowledge, especially receptive vocabulary knowledge, but there are still limitations on related studies. First, previous studies lack a combination of several extensive listening materials in a single study. For example, Brown, Waring, and Donkaewbua (2008) and Suggate, Lenhard, Neudecker, and Schneider (2013) required participants to select only stories to practice extensive listening; Yuksel and Tanriverdi (2009) asked participants to watch a popular American television series. Second, most research pays little attention to measure word aural forms in receptive vocabulary knowledge (Brown et al., 2008; Suggate et al., 2013). Thus, this study attempts to combine several types of extensive listening practice for students to practice to enhance their receptive vocabulary knowledge, specifically, both word meanings and aural forms. 
The present study is conducted to examine the effects of extensive listening on vocabulary learning, in this case, referring to receptive vocabulary knowledge of preintermediate students at The Asian International School.

Within the above aim, the study answers the question: To what extent does extensive listening affect the pre-intermediate students' receptive vocabulary knowledge at The Asian International School?

The hypothesis for this question is that students at the pre-intermediate level who participate in extensive listening at The Asian International School will have higher achievement on receptive vocabulary knowledge test scores than students who participate in intensive listening practice.

\section{Literature review}

\subsection{Intensive Listening (IL) and Extensive Listening (EL)}

IL and EL are two different ways to practice listening. In IL, listeners mostly focus on what they have heard precisely (Field, 2008; Rost, 1991, 2011). Otherwise, listeners could comprehend a huge amount of meaningful input while they are listening for pleasure in EL (McDonough \& Shaw, 1993, as cited in Kim, 2004; Milliner, 2017; Rost, 2011; Ucán, 2010; Waring, 2008). Since IL and EL are opposites, discussion on the differences between IL and EL is crucial. Firstly, learners who practice EL are not taught target words as IL practice, but they can acquire vocabulary incidentally. IL aims to teach learners new grammar and vocabulary (Chang, 2012; Renandya, 2011) while EL could help learners obtain vocabulary knowledge by meeting the word several times (Renandya, 2011). Secondly, learners listen for details in IL (Field, 2008) while they are provided lots of comprehensive inputs to foster their overall global comprehension (McDonough \& Shaw, 1993, as cited in Kim, 2004) and build their listening speed (Waring, 2008). Thirdly, IL may require learners to follow rigid lesson plans with a threestep sequence (Chang, 2012) while in EL, learners can listen whenever they are ready both inside and outside classrooms (Chang, 2012; Matsuo, 2015; Renandya, 2010; Renandya \& Farrell, 2011; Ucán, 2010; Waring, 2008). Another difference between IL and EL is shown in listening to materials. IL materials are often more difficult, lower speedy, and shorter than EL materials (Ferrato \& White, 2004, as cited in Bui \& Do, 2016). Hence, listeners are required to react to specific questions or tasks in IL (Field, 2008). However, listeners have no requirements as in IL (Chang, 2012). Then, the IL activities include pause and paraphrase, listening close, error identification, elicited repetition, word spotting, grammar processing, etc. to develop learners' listening strategies (Rost, 2011). EL provides several kinds of activities such as narrow listening, storytelling, repeated listening, dictation, etc. to focus on general understanding (Renandya, 2011, 2012). In brief, EL is a pleasant way to listen while IL has specific requirements.

\subsection{Receptive Vocabulary Knowledge (RVK)}

Receptive Vocabulary Knowledge (RVK) is considered as the learners' ability to understand a word in listening or reading texts. First of all, Harmer (2001) states that RVK is the learners' knowledge to recognize words when they hear or see the words. Similarly, learners can understand the words while they are reading or listening (Alkhofi, 2015; Faraj, 2015; Maskor \& Baharudin, 2016; Zhou, 2010) then also recalling the words (Hajiyeva, 2015) in RVK. Secondly, Nation (2001) and Hajiyeva (2015) also define RVK as passive vocabulary since outside stimuli could activate RVK. In short, if learners recognize a word when it appears in listening or reading texts, they may have receptive knowledge of that word. 
To measure RVK, it must be a measurement of how listeners understand the words by listening or reading them. Thus, it must be using receptive vocabulary measurement. One of the most appropriate types of measurement is the multiple-choice proposed by Nizonkiza (2016). Moreover, the test-takers in this measurement could be asked to translate the words from foreign language to the mother tongue or show word meanings (Šišková, 2016).

\subsection{The Receptive Vocabulary Knowledge test}

This study aims to examine the effects of EL on students' RVK, thus the measurement of vocabulary knowledge must be fulfilled the requirement of measuring RVK containing the recognition of word meanings and word aural forms. Fortunately, McLean, Kramer, and Beglar (2015) designed a Listening Vocabulary Levels Test (LVLT) to fill the gaps in the literature on word knowledge testing. The LVLT focuses on measuring RVK which includes both word meanings and word aural forms taken from the first five 1000-word frequency levels in Nation's (2012) British National Corpus/Corpus of Contemporary American English word lists and Coxhead's (2000) Academic Word List proposes (as cited in McLean et al., 2015). The LVLT which uses two languages is adapted from the Vocabulary Size Test version Japanese on Paul Nation's publication on Victoria University of Wellington's website. It is a bilingual format, and each distractor could be easier for the test-takers to show word meanings because direct translations could not absorb much cognition in the time constraint (McLean et al., 2015). The LVLT is guaranteed with strong validity when comparing with the Test of English for International Communication scores, carelessness, and guessing. The format of the test is fourmultiple-choice that is appropriate with Nizonkiza's (2016) receptive vocabulary measurement. Those strengths of the test prove that LVLT is an appropriate test to measure RVK including word meanings and word aural forms for diagnostic and achievement purposes.

\subsection{The effects of extensive listening on vocabulary learning}

The positive effects of EL on vocabulary learning have been by several researchers (Bozan, 2015; Brown et al., 2008; Bui \& Do, 2016; Chang, 2012; Mayora, 2017; Meier, 2015; Renandya, 2012; Suggate et al., 2013; Ucán, 2010; Widodo \& Rozak, 2016; Yuksel \& Tanriverdi, 2009). First, Brown et al. (2008) found that learners could acquire and retain more words in terms of recognition word meanings if they read while listening extensively to stories. Second, Yuksel and Tanriverdi (2009) stated that EL influenced Turkish learners' RVK by providing them a popular American Television series. Then, Ucán (2010) explored that EL developed and increased vocabulary size for 16 beginner students. Another research investigated 55 university English students' RVK and listening development by intensively and extensively listening to stories from audiobooks for 26 weeks (Chang, 2012). However, the results of this study were not as expected. The study found that learners who participated in IL to stories acquired more words than the ones in EL in the Vocabulary Level Tests. This result might be explained as because the control group had more chances to study every chapter with every detail from audiobooks while the experimental group just studied 15 easy audiobooks then took a comprehension check. Even though acquiring vocabulary in IL was more effective than EL, learners did enhance RVK in EL. Furthermore, it was found that EL could enhance learners' recognition of word aural forms (Renandya, 2012; Suggate et al., 2013). The measurement of word aural forms just stopped at simply choosing the suitable pictures by hearing words. Recently, research conducted by Bozan (2015) which combines several kinds of listening materials for EL practice showed that EL could enhance learners' use of grammar and vocabulary. However, the study tends to measure word meanings and written forms mostly. It lacks the measurement of word aural forms. Also, the participants were not required to report on 
what they've gained in the listening materials. It should have examined the participants' reports on what they practiced to make the results more compelling and reasonable. Meier (2015), Widodo and Rozak (2016), and Mayora (2017) also truly suggested the positive effects of EL to podcasts and videos on incidental vocabulary acquisition.

In Vietnam, previous studies paid little attention to the effects of EL on English vocabulary learning but focused on students' English language skills. For instance, Bui and Do's (2016) study found small and brief evidence that EL positively affects 49 pre-intermediate students' vocabulary size at Hanoi University of Business and Technology. In addition, V. T. Le (2018) investigated the effects of applying technology and social media on 204 grade 10 Vietnamese learners' vocabulary enhancement with the employment of pre- and post-course tests as research instruments. The participants joined in a six-week online course to practice extensive listening, speaking, and writing. The results showed that the participants could use more words in speaking. In short, EL does affect Vietnamese learners' vocabulary learning despite a small range of studies in this field.

In short, the results from previous studies prove that EL is highly effective in helping learners acquire vocabulary incidentally. Nevertheless, the review of the above studies has also indicated some shortcomings. First of all, a few studies measured learners' word aural forms in receptive vocabulary knowledge. This is not convincing enough since learners do not only learn word written forms or meanings but also aural forms. Moreover, listening is a receptive skill that focuses on recognizing words by hearing. Hence, it is crucial to choose an appropriate test for RVK including word aural forms. Second, previous studies mainly take advantage of one single material instead of combining several types of listening materials in EL. Therefore, EL might conclude a variety of listening materials for learners to choose to make use of EL's benefits effectively. To avoid stepping on the previous studies' inadequacies and to fill in the gaps, this study was conducted by following the rigid methodology below.

\section{Methodology}

\subsection{Research site and participants}

The site and the participants of the study were at The Asian International School, in Ho Chi Minh City, Vietnam. Students at this school have to spend all daytime for two programs: first, the Ministry of Education and Training Program in the mornings, and second, the International English Program in the afternoons. All the participants in this study are the preintermediate level of proficiency learners and at the age of 14. Most of the participants learned English from very young ages. They also have good opportunities to practice English at anytime and anywhere at school. To learn English, in the Ministry of Education and Training Program, they study the book "English 8" published by Vietnam Education Publisher. They also study five subjects including Listening, Speaking, Reading, Writing, and Grammar with the coursebook "Inside Language, Literacy, and Content" in the International English Program. Besides the advantages of mostly studying English in the study program, the participants also have good physical conditions from the school. The teachers were in charge of all subjects shared the same lesson plans as in the same curriculum for the participants. Also, the participants, in general, reported that they did not attend any English language training from other teachers or language centers outside classrooms. Hence, it can be inferred that the chosen participants had the same knowledge background at the beginning.

The participants were chosen by using convenience sampling due to the time constraint and the policy of the school. "A convenience sample is a group of individuals who 
(conveniently) are available for study" (Fraenkel \& Wallen, 2009, p. 98). Therefore, 80 participants were selected from four available classes in a population of 325 pre-intermediate students. Two classes were collected for a Control Group (CG) and the other two classes for an Experimental Group (EG). Forty participants in each group satisfied the requirement of an experimental study that has 30 participants minimum in each group (Fraenkel \& Wallen, 2009). They are Grade 8 students with a pre-intermediate level of proficiency. The participants in general learned English from very young ages and they had good chances to interact with English. They also have good opportunities to practice English at anytime and anywhere at school.

Table 1 below shows the gender distribution of the two groups.

\section{Table 1}

Participants' gender

\begin{tabular}{|l|l|l|l|}
\hline \multirow{2}{*}{} & \multicolumn{3}{|c|}{ Gender } \\
\cline { 2 - 5 } & \multicolumn{2}{|c|}{ Male } & \multicolumn{2}{c|}{ Female } & \multicolumn{1}{c|}{ Total } \\
\hline Control group & 15 & 25 & 40 \\
\hline Experimental Group & 14 & 26 & 40 \\
\hline
\end{tabular}

Source: The researcher's data analysis

As illustrated in Table 1, there were 40 students in the CG, including 15 males and 25 females. The EG composed of 14 males and 26 females, thus 40 students in total. The description of the two groups presents a strong equivalence in the number of participants and gender.

\subsection{Research design}

The study was conducted by following a quantitative base and the procedure of a quasiexperiment proposed by Fraenkel and Wallen (2009). Eighty participants from four classes were divided into two groups as the Control Group and Experimental Group as convenience sampling. The study included a pretest, then a treatment, and a posttest with LVLT to measure the participants' RVK. All the participants received the same formal curriculum with the coursebook which includes the same listening tasks or exercises in Listening subject. Added activities to the formal curriculum inside classrooms, the CG also practiced extra IL tasks or exercises and the EG received EL activities. The amount of time and the topics of listening materials for both two groups' practice were not different. Outside classrooms, the CG were required to practice IL and the EG practiced EL to make sure that the two groups had the same gained knowledge. The EG has demonstrated the benefits of EL and guided how to choose materials themselves. All participants have to report what they have done outside classrooms by submitting on listening journals each week to make sure that they did practice listening or not and the time they spent on listening was counted. Finally, they took the posttest after 12 weeks - the end of the semester. It is a suitable time for the participants to take the posttest second time avoiding remembering their answers for the first time that replicated the way in Brown et al. conducted the posttest (2008). Additionally, Brown et al. (2008) also recommended that the test's items in the posttest should be rearranged to manage the possible learning effect. Table 3.2 below presents all the major points of the research design. 


\section{Table 2}

The research designs

\begin{tabular}{|c|c|c|c|}
\hline & & Control Group (N=40) & Experimental Group $(\mathrm{N}=40)$ \\
\hline \multicolumn{2}{|l|}{ 1. Pretest } & LVLT & LVLT \\
\hline \multicolumn{2}{|c|}{ 2. Formal curriculum } & $\begin{array}{l}\text { "Inside Language, } \\
\text { Literacy, and Content" }\end{array}$ & $\begin{array}{l}\text { "Inside Language, Literacy, } \\
\text { and Content" }\end{array}$ \\
\hline \multirow{4}{*}{$\begin{array}{l}\text { 3. Teaching } \\
\text { and } \\
\text { treatment }\end{array}$} & \multirow[t]{2}{*}{ Inside classrooms } & IL practice & EL practice \\
\hline & & \multicolumn{2}{|c|}{$\begin{array}{l}\text { Same topics in listening to audiobooks, stories, podcasts, } \\
\text { TED talks, songs, watching films, and movie clips }\end{array}$} \\
\hline & Outside classrooms & IL practice & EL practice \\
\hline & $\begin{array}{l}\text { Choosing listening } \\
\text { materials }\end{array}$ & The researcher & $\begin{array}{l}\text { The researcher's suggestions } \\
\text { and the students }\end{array}$ \\
\hline \multicolumn{2}{|c|}{ 4. Listening journals } & one listening journal a week & one listening journal a week \\
\hline \multicolumn{2}{|l|}{ 5. Posttest } & LVLT & LVLT \\
\hline
\end{tabular}

Source: The researcher's data analysis

The LVLT was employed as a major instrument in this research. First, the LVLT which was used to measure RVK, including word meanings and word aural forms was adapted from McLean et al.'s (2015) original Japanese - English version. Due to LVLT's bilingual format, the test-takers could show their word meaning knowledge and each distractor could be less difficult. As stated by McLean et al. (2015), direct translations didn't require much cognition in the time constraint. The test was translated from English to Vietnamese by Nguyen and Truong and presented in the Vocabulary Size Test (bilingual Vietnamese version) on the website https://www.victoria.ac.nz/lals/about/staff/paul-nation\#publications (Nation, 2012). Some not translated items were continued to translate by the researcher. Then, those items were checked and reviewed by three experienced Vietnamese teachers of the research site and rechecked by another experienced teacher who is a Doctor of Philosophy. The researcher asked and got approval from the school to run those tests in the two classes. The bilingual format of the test has been considered suitable for the grade 8 learners' level of English proficiency by reviewers of the test.

Lastly, the LVLT Vietnamese version was piloted in March and August 2018 to revise some items which could make test-takers understand in different ways. After pilots, the researcher selected the first three levels of the test to be appropriate with the participants' level and the time constraint inside classrooms. The LVLT was paper-based and lasted around 15 minutes. There are 3 levels in the test with 24 items in each level. Each correct answer for each item will be marked as 1 point. Thus, the total points of the test are 72 points. Here is one example practice question and the correct answer:

[Test-takers hear: 'School: This is a big school.']
1. A. ngân hàng
B. sinh vật biển
(C.) trường học
D. ngôi nhà

The study also used listening journals to manage the participants' practice and time reported. N. Schmidt (2016) suggested that a listening journal is a suitable aid for learners to follow instructions and report their practice during the experiment. The listening journal contains 
the requirements for both IL and EL practice. With the advantages of listening journal, this study adapted Schmidt's version to make it more appropriate with the participants and study design. For instance, the CG practiced one given listening text each week then reported new or interesting words or phrases that they have learned from the provided material. The EG could choose the listening text(s) from the provided sources or they found out. Then, they provided their general understanding of the text by answering what the listening text was. To ensure the reliability and validity of the listening journal, the research explained and instructed clearly its purpose to the participants. The students understood that the listening journal would not be evaluated and assessed, and the information in the journal would be kept confidential. The answer was free to make sure that students did not have any pressure to do listening to journals. Both the two groups were required to report how long it took to finish the given tasks finally to a self-assessment to reflect the speed, vocabulary, pronunciation, and content of the listening text(s) at the end of listening journals. What they have done was examined to guarantee that they listened to the instructions in choosing materials and whether they have listened or not. Also, the time spent on listening was reported to see if listening practice affected their RVK improvement or not. In this study, the listening journal was used as a reference for the student practice with IL and EL, and the data from the listening journal will be analyzed and discussed in investigating the relationship between listening practice and RVK.

The experiment was carried for five months from August to December 2018. The collected data was analyzed by using a paired-samples t-test, an independence-samples t-test, $r$ square, and scatterplots. First, the paired-samples t-test was used to investigate the differences between the pretest and posttest scores (Saka, 2015). Second, the independence-samples t-test was fitting to examine the differences between the mean scores between two different groups (Pallant, 2007). Third, the $r$ square and scatterplots were conducted and drawn to see the relationship between hours of listening practice collected in listening journals and EL or IL. The strength of the linear relationship between two variables and the nature of the relationship is presented in the $r$ square and scatterplots, respectively (Pallant, 2007).

\section{Results}

The results of this study are presented in Table 3 by analyzing the RVK measurement in the pretest and posttest scores.

\section{Table 3}

Results of the participants' RVK test scores

\begin{tabular}{|c|c|c|c|c|}
\hline & Pretest & Posttest & \multirow{2}{*}{$\begin{array}{c}\text { Mean } \\
\text { difference }\end{array}$} & \multirow{2}{*}{$\begin{array}{c}\text { Sig. (2-tailed) of } \\
\text { paired-samples t-test }\end{array}$} \\
\hline & \multicolumn{2}{|c|}{ Mean } & & \\
\hline Control group & 51.575 & 53.20 & 1.63 & 0.11 \\
\hline Experimental group & 52.45 & 56.88 & 4.43 & 0.00 \\
\hline Mean difference & 0.88 & 3.68 & & \\
\hline $\begin{array}{l}\text { Sig. (2-tailed) of independent- } \\
\text { samples t-test }\end{array}$ & 0.65 & 0.03 & & \\
\hline
\end{tabular}

Source: Data analysis result of the research

As illustrated in Table 3, first, the mean difference of the pretest scores of the CG and EG is 0.88 , and $p$-value (.65) is much more than alpha (.05). Hence, there is no significant difference 
between the EG and CG in the pretest scores even though the mean scores of the EG are higher than the ones of the CG. It could be inferred that the participants in the two groups had similar RVK before conducting the treatment. Second, there is a significant difference between the CG and EG in the posttest results and the EG has remarkably higher posttest scores than the CG has. As can be seen in the table, the mean difference between the two groups' posttest scores is 3.68, and $p$-value (.03) is less than alpha (.05). To sum up, EL improved the EG's RVK significantly more than IL improved the CG's RVK.

From Table 3, the GC has the mean difference between the pretest and posttest results 1.63 , and $p$-value (.11) is more than alpha (.05). Hence, there is no significant difference between the pretest and posttest scores in the CG. It can be inferred that the CG enhanced their RVK but this improvement was not incredibly. Otherwise, the EG has the mean difference between the pretest and posttest scores 4.43, and $p$-value (.00) is less than alpha (.05). The EG has a significant difference between the pretest and posttest results and the posttest scores are higher than the pretest scores. Understandably, EG improved significantly in their RVK. In conclusion, after the treatment, the participants in the EG improved significantly in their RVK, but the ones in the CG did not.

In addition, the results from listening journals show that each participant in the CG and EG spent about 3 hours and 4 hours respectively during 12 weeks. The relationship between the hours of listening practice and posttest scores in the CG and EG was illustrated in Table 4 and Figures 1, 2, 3, and 4 below.

\section{Table 4}

The $r$ squares of the $\mathrm{CG}$ and $\mathrm{EG}$

\begin{tabular}{|l|c|c|c|}
\hline \multicolumn{1}{|c|}{ Model } & Dependent Variable & Sig. & R Square \\
\hline 1. Time spent on IL practice (seconds) & Posttest scores & 0.47 & 0.01 \\
\hline 2. Time spent on IL practice (seconds) & $\begin{array}{l}\text { Improvement of RVK from } \\
\text { the pretest to posttest scores }\end{array}$ & 0.78 & 0.002 \\
\hline 3. Time spent on EL practice (seconds) & Posttest scores & 0.26 & 0.03 \\
\hline 4. Time spent on EL practice (seconds) & $\begin{array}{l}\text { Improvement of RVK from } \\
\text { the pretest to posttest scores }\end{array}$ & 0.65 & 0.01 \\
\hline
\end{tabular}

Source: Data analysis result of the research 


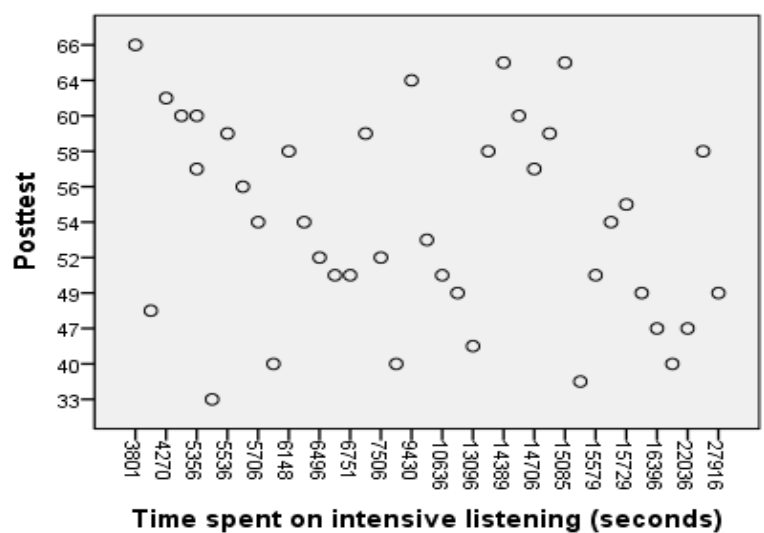

Figure 1. The relationship between listening practice and RVK in the CG

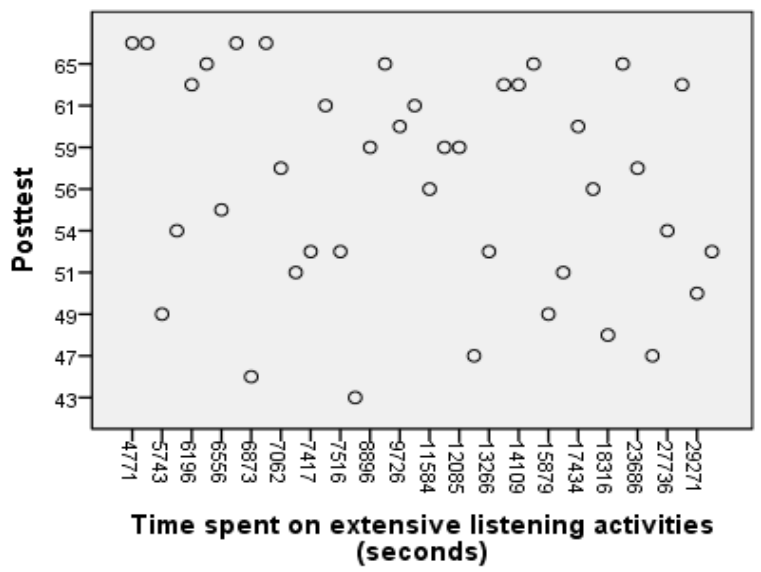

Figure 2. The relationship between listening practice and the improvement of RVK in the CG

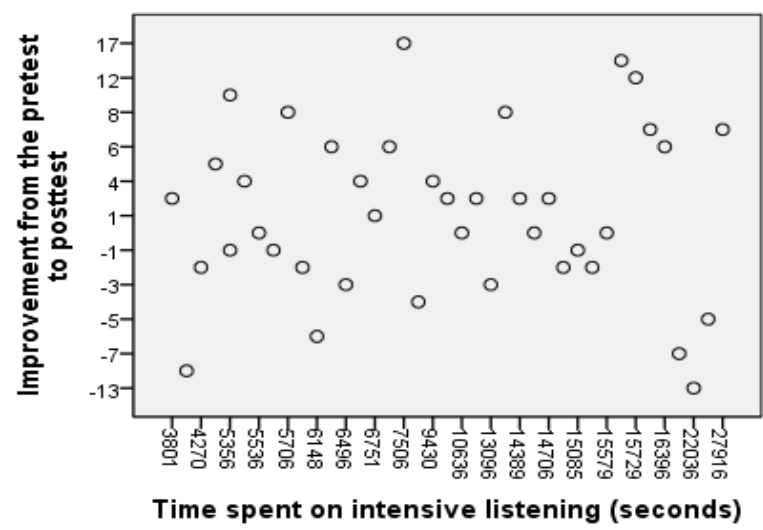

Figure 3. The relationship between listening practice and RVK in the EG

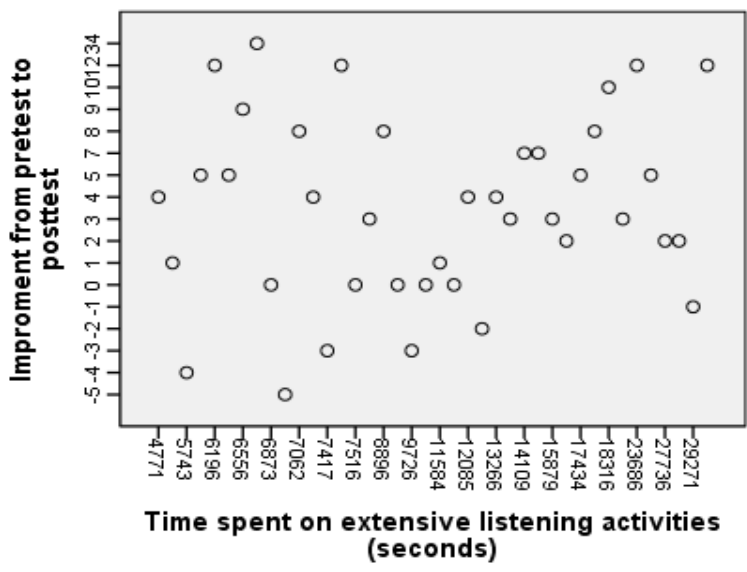

Figure 4. The relationship between listening practice and the improvement of RVK in the EG

As demonstrated in Table 4 and Figure 1, 2, the $r$ squares for model 1 and 2 are .01 and .002 that mean the independence variable (IL practice) could explain $1 \%$ and $0.2 \%$ respectively of the differences in the dependent variable (RVK). A correlation of 0 presents no relationship, 1.0 - a strong positive correlation, -1.0 - a negative correlation (Pallant, 2007). Hence, the $r$ squares found in the two models shows that there is a relationship between the hours of listening practice and posttest scores in the CG but not significant $(p=.47, .78>$ alpha $=.05)$. Besides, the scatterplots of models 1 and 2 described the data points spread around Figures 1 and 2 that present a low correlation. As a conclusion, the relationship between IL practice and RVK of the CG was not strong but somewhat positive.

Also, as can be observed in Table 4 and Figure 3, 4, the $r$ squares for model 3 and 4 are .03 and .01 and $p$-value $(=.26, .65)$ are higher than alpha. The scatterplots are spread all over Figures 3 and 4 . Hence, there was a weak relationship between listening practice and RVK in the EG and this relationship was somewhat positive. However, the $r$ squares in models 3 and 4 are higher than those in models 1 and 2, respectively. It demonstrated that the relationship between EL practice and RVK was somewhat stronger than the relationship between IL practice and RVK. To sum up, the relationship between EL practice and RVK was somewhat positive and stronger than the one between IL practice and RVK. 
Pallant (2007) proposed that level of significance could prove the level of confidence we might have in the results and the level of significance might be affected by the small sample size of the research (2007). For instance, moderate correlations could be found in a small sample size with 30 participants that lead the $p$-value may not meet the traditional level of statistical significance $(\mathrm{p}<.05)$. Therefore, the significances of the four models were higher than .05 which might be caused by the small sample size (40 participants). Eventually, there were positive but not strong relationships between listening practice and RVK of both the CG and EG.

\section{Discussions}

The results of the study state that the students who experienced EL practice have higher improvement on RVK than the ones who did IL practice. The research findings confirm the hypothesis of the study that the participants who took part in EL practice would have higher achievement on RVK test scores than the ones who joined in IL practice. The clearest finding to emerge from this study is that the EG's posttest scores are significantly higher than the ones of the CG. Moreover, the findings present that between the pretest and posttest of the EG there is a significant difference while there is no significant difference in the CG. Even though the scores of the CG are higher after the posttest, the CG's improvement is not notable as in the EG. It can be accepted that the participants' RVK, especially word meanings and word aural forms, may be enhanced significantly thanks to EL. This finding could give a useful contribution to the scarcity of the findings from previous studies (Bozan, 2015; Brown et al., 2008; Bui \& Do, 2016; Chang, 2012; Meier, 2015; Suggate et al., 2013; Widodo \& Rozak, 2016; Yuksel \& Tanriverdi, 2009) that a benefit of EL is increasing learners' RVK including word aural forms.

Furthermore, it was found that there are not strong but somewhat positive relationships between EL practice and RVK. This relationship is rather stronger than the relationship between IL practice and RVK. The result is not as expected but reflects the findings of Bozan's (2015) study that found if the students practiced EL more, they would have higher results on a proficiency examination. Each participant in Bozan's study spent 46.47 hours on average per 8 weeks to practice EL while one participant of the EG in this study spent about 4 hours per 12 weeks. The little time in practicing could lead to a few exposures which the EG might not get enough for incidental vocabulary acquisition happening (Brown et al., 2008; van Zeeland \& Schmitt, 2013). It could be an explanation of why these relationships are not significant. Also, several participants in the study might affect these relationships. Anyway, on a final note, the more the participants practice EL, somewhat the higher results they may have on RVK improvement. It is also worth noting, the more the participants practice EL, the higher RVK improvement they have to some degree.

\section{Conclusions}

With the determination to explore the effects of EL on the pre-intermediate learners' vocabulary learning at The Asian International School, the present study finished with impressive results which answer for the research question "To what extent does extensive listening affect the pre-intermediate students' receptive vocabulary knowledge at The Asian International School?". First, the study has indicated that EL could help to improve the participants' RVK significantly, word meanings and word aural forms. Second, the relationship between EL practice and RVK was positive but not strong enough due to the time limitation in practicing. To some extent, these findings demonstrate that the more the students practice EL, the higher results they somewhat have on RVK improvement. The results are not as remarkable as expected, but it could uncover that learners who spend more time on doing EL practice may get more advantages in vocabulary learning than the ones who do not. By way of conclusion, 
based on the evidence found in the experiment, this study proves that EL can help to enhance learners' RVK, containing word meanings and word aural forms. Also, the more the learners practice EL, the higher results they somewhat have in their RVK improvement.

The findings make two major contributions to the current literature on teaching and learning of vocabulary, especially in the Vietnamese context. First of all, the study proves that EL is an effective way to improve learners' vocabulary learning, RVK specifically that a few studies have explored. Second, measurement of word aural forms in RVK is also another issue that rare studies paid attention. Thus, there are some pedagogical implications for administrators, teachers, and students to learn from this research. First, EL should be considered to integrate into the formal English curriculum as an extracurricular activity in foreign language learning. Second, teachers should provide students a large collection of EL materials; instruct them on how to choose appropriate listening materials and how to carry out EL practice effectively for them to motivate them on listening. Third, it may be better if EL is practiced with a combination of both inside and outside classrooms so that students will have more opportunities, for example, time and gadgets to listen and learn more vocabulary than practicing inside classrooms only.

The research study still has some limitations due to the time constraint and small sample size. Firstly, the experiment just lasted for a short time with only 12 weeks - one semester that might affect the study to get more results in vocabulary learning because word acquisition maybe happens in a long time. Future studies could expand the time to have better results. Secondly, the significant relationship between EL practice and RVK may be affected by the small sample size. Related studies could choose more participants to have better achievement. From the limitations, this research has thrown up three crucial issues in need of further exploration. First and foremost, future work needs to investigate whether EL practice affects vocabulary learning both in receptive and productive vocabulary knowledge. Second, further related could recruit more participants and spend more time in experiments to get a stronger relationship between EL practice and RVK. Last but not least, it is worth examining the effects of EL practice on other proficiency levels to get diverse results. Overall conclusion, further studies could look at these suggestions to achieve more attractive results in carrying EL for learning vocabulary.

\section{References}

Aguilera, L. C., \& Filologia, L. E. (2012, December). PublicacionesDidacticas. Retrieved February 3, 2018, from http://publicacionesdidacticas.com

Alkhofi, A. (2015). Comparing the receptive vocabulary knowledge of intermediate-level students of different native languages in an intensive English program (Master's thesis, University of Central Florida, Orlando, Florida, United States). Retrieved February 5, 2018, from https://stars.library.ucf.edu/etd/48

Bozan, E. (2015). The effects of extensive listening for pleasure on the global proficiency level of EFL learners in an input-based setting (Doctoral dissertation, University of Kansas, United States). Retrieved February 6, 2018, from https://kuscholarworks.ku.edu/bitstream/handle/1808/ 21594/BOZAN_ku_0099M_14230_DATA_1.pdf?sequence=1

Brown, R., Waring, R., \& Donkaewbua, S. (2008). Incidental vocabulary acquisition from reading, reading-while-listening, and listening to stories. Reading in a Foreign Language, 20(2), 136-163. 
Bui, M. T., \& Do, T. P. T. (2016, August 11-13). Using podcasts for extensive listening to improve students' listening skills. Paper presented at the 7th International Conference on TESOL: Innovations in English Language Teaching and Learning.

Chang, C. S. A. (2012). Gains to L2 learners from extensive listening: Listening development, vocabulary acquisition and perceptions of the intervention. Hong Kong Journal of Applied Linguistics, 14, 25-47.

Faraj, A. K. (2015). Effective strategies for turning receptive vocabulary into productive vocabulary in EFL context. Journal of Education and Practice, 6(27), 10-19.

Field, J. (2008). Listening in the language classroom. Cambridge, UK: Cambridge University Press.

Fraenkel, J. R., \& Wallen, N. E. (2009). How to design and evaluate research in education. New York, NY: McGraw-Hill.

Hajiyeva, K. (2015). Exploring the relationship between receptive and productive vocabulary sizes and their increased use by Azerbaijani English majors. English Language Teaching, 8(8), 31-45. doi:10.5539/elt.v8n8p31

Harmer, J. (2001). The practice of English language teaching. London/New York: Longman.

Kim, J. H. (2004). Intensive or extensive listening for 12 beginners? English Teaching, 59(3), 93-114.

Larsson, T. (2014). Vocabulary learning: A study of students' and teachers' attitudes towards English vocabulary learning in lower secondary school (Bachelor's thesis, Karlstads University, Karlstad, Sweden). Retrieved February 7, 2018, from http://kau.divaportal.org/

Le, H. P. H. (2001, September). Towards Vygotskian approaches in teaching English in Vietnam. Teacher's Edition, 26-31.

Le, V. T. (2018). Social media in learning English in Vietnam (Doctoral dissertation, University of Canterbury, New Zealand). Retrieved February 8, 2018, from https://www.canterbury.ac.nz

Maskor, Z. M., \& Baharudin, H. (2016). Receptive vocabulary knowledge or productive vocabulary knowledge in writing skill, which one important? International Journal of Academic Research in Business and Social Sciences, 6(11), 261-271. doi:10.6007/IJARBSS/v6-i11/2395

Matsuo, S. (2015). Extensive listening inside and outside the classroom. Kwansei Gakuin University Humanities Review, 20(1), 109-115.

Mayora, C. A. (2017). Extensive listening in a Colombian university: Process, product, and perceptions. HOW, 24(1), 101-121. doi:10.19183/how.24.1.311

McLean, S., Kramer, B., \& Beglar, D. (2015). The creation and validation of a listening vocabulary levels test. Language Teaching Research, 19(6), 741-760. doi:10.1177/1362168814567889

Meier, A. (2015). L2 incidental vocabulary acquisition through extensive listening to podcasts. APPLE Award Winning Papers in TESOL \& AL, 15(2). doi:10.7916/D8M04J33

Milliner, B. (2017). Five online resources for extensive listening in the Japanese EFL classroom. Accents Asia, 9(2), 1-10. 
Nation, I. S. (2001). Learning vocabulary in another language. Cambridge, UK: Cambridge University Press.

Nation, I. S. (2007, January 31st). The four strands. Innovation in Language Learning and Teaching, 1(1), 1-12.

Nation, I. S. (2008). Teaching vocabulary: Strategies and techniques. Boston, MA: Heinle.

Nation, I. S. (2012). The BNC/COCA word family lists. Retrieved March 10, 2020, from Victoria University of Wellington website: https:/www.victoria.ac.nz/lals/about/staff/paulnation\#vocab-lists

Nguyen, H. T. T., \& Pham, M. T. T. (2016). Difficulties in teaching English for specific purposes: Empirical study at Vietnam universities. Higher Education Studies, 6(2), 154161. doi:10.5539/hes.v6n2p154

Nizonkiza, D. (2016). First-year university students' receptive and productive use of academic vocabulary. Stellenbosch Papers in Linguistics, 45, 169-187. doi:10.5774/45-0-215

Pallant, J. (2007). SPSS survival manual a step by step guide to data analysis using SPSS for Windows (3rd ed.). Maidenhead, UK: Open University Press.

Rahmawati, N. (2012). Difficulties in English vocabulary learning experienced by the eigth grade students of SMP Negeri I Borobudur in the acedemic year of 2011/2012 (Master's thesis, State Uneversity of Yogyakarta, Indonesia). Retrieved February 9, 2018, from http://eprints.uny.ac.id/8378/1/1-05202244164.pdf

Renandya, W. A. (2010, November). Does practice make perfect? An interview with Dr. Willy Renandya / Interviewer: KATE Forum. Retrieved February 10, 2020, from https://www.academia.edu/2069211/Does_practice_make_perfect_An_interview_with_D r_Willy_A_Renandya

Renandya, W. A. (2011). Extensive listening in the language classroom. In H. P. Widodo \& A. Cirocki (Eds.), Innovation and creativity in ELT methodology (pp. 28-41). New York, NY: Nova.

Renandya, W. A. (2012). Materials and methods for extensive listening. Plenary Paper Presentation -59th TEFLIN International Conference, Surabaya, Indonesia.

Renandya, W. A., \& Farrell, T. S. C. (2011, January 1). 'Teacher, the tape is too fast!' Extensive listening in ELT. ELT Journal, 64(1), 52-59. doi:10.1093/elt/ccq015

Rohmatillah, R. (2017). A study on students' difficulties in learning. English Education: Jurnal Tadris Bahasa Inggris, 6(1), 75-93. doi:10.24042/ee-jtbi.v6i1.520

Rost, M. (1991). Listening in action. Upper Saddle River, NJ: Prentice Hall.

Rost, M. (2011). Teaching and researching: Listening (2nd ed.). Harlow, UK: Pearson.

Saka, Z. (2015). The effectiveness of audiobooks on pronunciation skills of EFL learners at different proficiency levels (Unpublished master's thesis). Bilkent University, Ankara, Turkey. Retrieved February 11, 2018, from http://www.thesis.bilkent.edu.tr/0006898.pdf

Schmidt, A. (2016). Listening journals for extensive and intensive listening practice. English Teaching Forum, 54(2), 2-11.

Schmitt, N. (2000). Vocabulary in language teaching. Cambridge, UK: Cambridge University Press. 
Sedau, E. A. (2004). Exploring vocabulary difficult in English literature classroom and sholutions: An action reasearch (Bachelor's thesis, University Malaysia Sarawak, Malaysia). Retrieved February 12, 2018, from https://www.semanticscholar.org

Šišková, Z. (2016). The relationship between receptive and productive vocabulary of Slavic EFL learners. Topics in Linguistics, 17(2), 26-40. doi:10.1515/topling-2016-0011

Suggate, S. P., Lenhard, W., Neudecker, E., \& Schneider, W. (2013). Incidental vocabulary acquisition from stories: Second and fourth graders learn more from listening than reading. First Language, 33(6), 551-571. doi:10.1177/0142723713503144

Tavil, Z. M. (2010). Integrating listening and speaking skills to facilitate English language learners' communicative competence. Procedia-Social and Behavioral Sciences, 9, 765770. doi:10.1016/j.sbspro.2010.12.231

Thornburry, S., \& Harmer, J. (2002). How to teach vocabulary. Malaysia: Pearson Education Limited 2002.

Ucán, J. L. B. (2010). Benefits of using extensive listening in ELT. Memorias Del Vi Foro Estudios En Lenguas Internacional, (FEL 2010), 36-44.

van Zeeland, H., \& Schmitt, N. (2013). Incidental vocabulary acquisition through L2 listening: A dimensions approach. System, 41(3), 609-624. doi:10.1016/j.system.2013.07.012

Viera, R. T. (2017). Vocabulary knowledge in the production of written texts: A case study on EFL language learners. Revista Tecnológica-ESPOL, 30(3), 89-105.

Waring, R. (2008). Extensive reading in Japan: Starting an extensive listening program. The Journal of the JALT Extensive Reading Special Interest Group, 1(1), 7-9.

Widodo, H. P., \& Rozak, R. R. (2016). Engaging student teachers in collaborative and reflective online video-assisted extensive listening in an Indonesian initial teacher education (ITE) context. Electronic Journal of Foreign Language Teaching, 13(2), 229-244.

Yuksel, D., \& Tanriverdi, B. (2009). Effects of watching captioned movie clip on vocabulary development of EFL learners. TOJET: The Turkish Online Journal of Educational Technology, 8(2), 48-54.

Zabidin, N. B. (2015). The use of humourous texts in improving ESL learners' vocabulary comprehension and retention. English Language Teaching, 8(9), 104-111. doi:10.5539/elt.v8n9p104

Zhou, S. (2010). Comparing receptive and productive academic vocabulary knowledge of Chinese EFL learners. Asian Social Science, 6(10), 14-19. doi:10.5539/ass.v6n10p14 